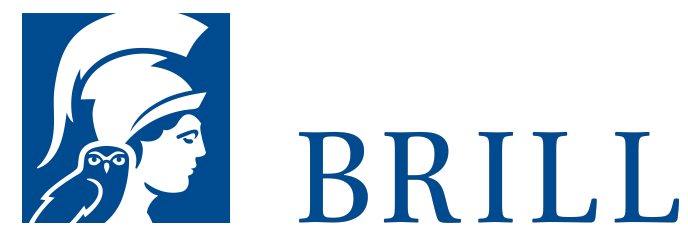

\title{
Corporate Jurisdiction, Academic Heresy, and Fraternal Correction at the University of Paris, 1200-1400
}

Author: Gregory S. Moule

In Corporate Jurisdiction, Academic Heresy, and Fraternal Correction at the University of Paris, 1200-1400, Gregory S. Moule explains how the theological faculty acquired independent jurisdiction over cases of academic heresy among its membership. He convincingly demonstrates that the faculty's jurisdiction and procedures were modelled on the pattern of a bishop and his cathedral canons.

Gregory S. Moule's analysis of Pierre D'Ailly's Apologia confirms the faculty's jurisdiction and establishes that the censures of Denis Foulechat and John of Monteson were instances of judicial rather than fraternal correction. Medieval discussions of Judas Iscariot further clarify fraternal correction's role in the process of censure. Canon law, corporate theory, scholastic theology, and biblical commentary are employed to produce a wide-ranging, original, and thought-provoking study.

Readership

All interested in the history of the University of Paris and its corporate development; anyone interested in heresy, fraternal correction, Pierre D'Ailly, Denis Foulechat, John of Monteson, and Judas Iscariot.

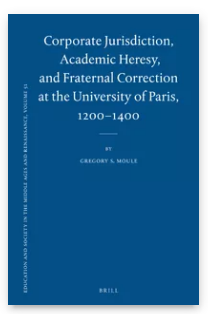

Pages: $390 \mathrm{pp}$.

Language:

English

Subjects:

Medieval

History, History, Intellectual

History, History, Church History, History, Legal

History, History, Legal History, International

Law

Publisher: Brill

Series:

Education and

Society in the

Middle Ages and

Renaissance,

Volume: $5^{1}$

E-Book (PDF)

Released online: O2 May 2016

ISBN: 978-90-

o4-31133-6

List price

USD $\$ 208.00$

Hardback

Publication date: 19 May 2016

ISBN: 978-90-

04-31132-9 
Gregory S. Moule, Ph.D. (1999), University of WisconsinMadison, is a Teacher of Spanish in the Philadelphia Public Schools. He is an independent scholar working in the field of Medieval Intellectual History. This is his first publication.

For more information see brill.com

\begin{abstract}
Order information: Order online at brill.com +44330 333 oo49 | customerservices@brill.com Submission information: brill.com/authors
\end{abstract}

Titles published by Brill | Fink, Brill | mentis or Brill | Schöningh: +49(o)71 5413279216 | brill@brocom.de 